\title{
SOCIAL RESPONSIBILITY AND SOCIAL COHESION AS DRIVERS IN THE SUSTAINABLE DEVELOPMENT OF UNIVERSITIES
}

\author{
Maryna Dielini ${ }^{1}$, Marja Nesterova $^{2}$, Iryna Dobronravova ${ }^{3}$
}

\begin{abstract}
The purpose of this article is to theoretically, methodologically and practically explore social responsibility and social cohesion and justify their role as driving forces in the sustainable development of universities. This paper focuses on the rationale for various aspects of the development of social responsibility and social cohesion, and specifically in higher education. The article defines the importance of the values of social cohesion and social development and their implementation in the education of socially responsible youth. Listed the main categories in which the social responsibility of the higher education can be determined and applied for the educational management effectiveness. This article aims to show the role of social cohesion and social responsibility in the implementation of the principles of sustainable development, and to reveal the relations between the values of social cohesion and social responsibility and the 17 UN Sustainable Development Goals (SDGs). Methodology. Scientific analysis is carried out with the help of an interdisciplinary system of methods, namely, system analysis, interviewing, statistical data analysis, comparison, etc. Social synergetics and system approach are applied to the issues of education management. Results. The methodological approaches to the formation of modern educational and management models for universities are considered. The model of the social cohesion of the university community is analyzed. The university management strategy based on the values and principles of social responsibility and social cohesion is described. Ways to improve the economic and managerial efficiency of universities and society, respectively, are considered. The process of self-organization in education management and parameters of its ordering are defined. The most significant scientific results: the attitude and development of such values as social responsibility and social cohesion in the Ukrainian educational community were investigated; the sustainable development of universities as the best practice and factor of influence on socio-economic development was determined; the role of social responsibility and social cohesion as parameters of order in enhancing the sustainable development of universities and society respectively was substantiated. The practical significance of the study lies in the actualization of the need to develop social responsibility and social cohesion in the Ukrainian educational community, which is confirmed by statistical data, as well as the possibility of their application in the educational process and value-based management of education. The use of these results in the practice of education management allows us to create a model of social responsibility of universities and outline the directions of its implementation, to develop and implement a mechanism for monitoring the implementation of social responsibility, to study the actual level of social cohesion of the university community, to suggest ways for its further development, aimed at improving the competitiveness of universities in a globalized environment. Value/originality. The originality of the study lies in the combination of the two key values of the EU and their correspondence to the SDGs and the sustainable development of universities on the basis of value-based education management. A social synergetic approach is applied to issues of educational governance.
\end{abstract}

Key words: educational management, self-organization, social responsibility, social cohesion, sustainable development, synergetics, synergy, university, values.

JEL Classification: A22, B41, B49, 121, 125

\footnotetext{
Corresponding author:

${ }^{1}$ National University of Life and Environmental Sciences of Ukraine, Ukraine.

E-mail: maryna_dielini@nubip.edu.ua

ORCID: https://orcid.org/0000-0003-1016-2305

${ }^{2}$ National Pedagogical Dragomanov University, Ukraine.

E-mail:marja@nesterova.com.ua

ORCID: https://orcid.org/0000-0001-6703-7797

${ }^{3}$ Taras Shevchenko National University of Kyiv, Ukraine.

E-mail: dobronra@ukr.net

ORCID: https://orcid.org/0000-0002-8767-4045
} 


\section{Introduction}

Nowadays, it can be considered sustainable development as one of the important development strategies because of its importance for socio-economic development. Synergetics is an important theory that studies an open complex system (Haken, 1996; Jingyan, 2010). From a synergetic perspective, this article analyzes and discusses synergy and evolution in a sustainable development system, and offers solutions for educational management with some formations from synergetics for reference. In the face of the complexity of current and future global challenges, higher education has a social responsibility to improve our understanding of, and ability to respond to, multifaceted problems involving social, economic, scientific and cultural aspects. It must lead society to create global knowledge that responds to the global challenges, including food security, climate change, water allocation, intercultural dialogue, deployment of renewable energy, and healthcare.

Higher education should not only provide solid skills for present and future generations, but also contribute to the education of socially responsible citizens who seek to create peace, protect human rights and defend the values of democracy. Thus, such an issue is part of sustainable development because it concerns future generations.

Social responsibility, which can be seen as a valuable thing, can be formulated as the responsibility of individuals for their actions to society. This responsibility can manifest itself in the form of one's own behavior, attitudes toward others, and actions aimed at raising a socially responsible generation. This effect is characteristic of all types of systems with a human aspect, in particular of university communities. Therefore, it can be assumed that social responsibility and social cohesion, respectively, are the key factors in the sustainable development of education, as it provides care for future generations and thus forms a worldview through the prism of responsibility for one's actions.

The concept of "sustainable development" works only in the context of nonlinear theories of selforganization created on the basis of synergetic methodology. This means that it is worth considering universities as open systems which are maintained by constant change within the environment. The environment for the university is society. The university as a scientific social institution needs to receive resources from society, namely financial, material, human, cultural, and so on. What kind of resources should universities provide for society to be an open system? It should be primarily human resources, specifically young educated people. In addition, the scientific achievements of research are necessarily part of the spiritual output of universities.
The connection of these two tasks is one of the conditions that make the state of university life nonlinear. It is non-linearity that is the most important condition for the self-organization of new complex systems (Dobronravova, 2001). It seems obvious that for non-linearity as a condition of its self-organization, universities should receive sufficient resources from society. However, it is not always clear what it means for universities to be open to society. The main point of this paper is to be socially responsible. Spontaneous self-organization of collectives with social cohesion can become autopoiesis based on the joint actions of teachers and students (Dobronravova, 2021). The governing parameters of self-organization are the values of society as an environment for which the university is open.

\section{Theoretical background of the research}

Sustainable development should be conditioned by the parameters of the social order. It can be assumed that it must be a process of social self-organization, namely the process of the development of social synergy. In this context, it can be assumed that social cohesion is directly related to the level of social synergy. In scientific discourse, the term synergy was used in neuromuscular physiology by Charles Scott Sherrington to describe the integrative action of the nervous system in 1916. The concept as a process related to self-organization was further developed by theoretical physicist Hermann Haken (Haken, 1995, 1996), the biologist, Director of the Institute for the Study of Complex Systems Peter Corning(2011), and Klaus Jafffe (Jaffe, 2010, 2021). Social synergy is deeply related to connection and cooperation (some of the most important attributes of social cohesion and social self-organization). Social selforganization is based on cooperation as well as social cohesion and social responsibility. In a general sense, cooperation is important in behavioral interactions, biological evolution, sociobiology, cultural dynamics, education, and collective intelligence, but the features that allow it to be successful are not well known (Montoreano, Jaffe, 2013).

This aspect of cooperation and some other social aspects of synergetic theory, in particular, selforganization, are reflected in the studies of domestic (L. Bevzenko, L. Gorbunova, I. Dobronravova, M. Nesterova, O. Voznyuk, etc.) and foreign (V. Arshinov, P. Bourdieu, V. Budanov, P. Checkland, H. Haken, K. Jaffe, L. Jingan, E. Knyazeva, A. Nazaretyan, I. Prigozhin, et al.) scientists who use the synergetic paradigm to analyze social, economic and, specifically, educational and managerial processes.

Synergetics began with the study of natural processes (H. Haken's laser radiation, I. Prigozhin's autocatalysis phenomena, etc.). Later synergetic studies of self- 
organization phenomena were applied to the study of socio-economic processes. One example was the article "Self-Organizing Society", which investigated societies with high social synergy (characterized by consensus) (Haken, 1996). A similar idea of social energy was discovered by R. Benedict in further studies of social cooperation in primitive communities. There is a connection between high social energy (which develops in people such social attitudes as altruism and mutual assistance) and high levels of synergy (which manifests itself in low levels of aggression and high levels of cooperation) (Benedict, R., 1970). Such societies are characterized by a high degree of trust, a sense of responsibility, and minimal centralization. Therefore, they can be considered as stable social systems.

\section{Unsolved part of the problem}

Taking social responsibility as the university's social responsibility, it can be distinguished different directions in which it can manifest itself. Firstly, the upbringing of socially responsible young people. Secondly, social responsibility to the students of the university. And it is on this basis that the university's social program will be formed. However, activities in both of these areas will be more effective and identify a truly socially responsible university. The authorities, university management, and society should realize the importance of higher education in the formation of socially responsible young people. Which can be done in many ways and in the same areas as in business. This will improve the quality of university education, promoting socially responsible values, mandatory teaching of CSR disciplines, student and university participation in community and volunteer activities, etc. This will create an important layer of socially responsible youth, which is not only a subject of society, but also a subject of business (getting a job or forming their own business structure) and the state (if the work is related to this area). In this case, socially responsible values are automatically transferred from the university to other structures, which confirms the relevance and importance of this area of research.
In addition, integrity is the basis for responsible action by universities. For several years it has been possible to observe increased attention and real action by the Ministry of Education and Science of Ukraine and universities individually to build a strong system of academic integrity and to improve the level of our science. It is hoped that this is a big step toward the sustainable development of universities.

\section{Methodology of research}

The most effective methodology in the field of sustainability is synergetics, and it is the best method for complex non-linear systems and processes. This gives a general framework for consideration of the problem. This approach allows to identify the key factors (parameters of control and order) of social self-organization that make a social system sustainable. Presumably, one of these parameters of order for the university is the social cohesion of the university community.

To conduct research on social cohesion in the university community, the Social Cohesion Model developed by the Bertelsmann Stiftung was used. Originally the methodology of Bertelslmann Stiftung was published in the report "The Social Cohesion Radar - An international Comparison of Social Cohesion" (2013). A team of researchers from Jacobs University Bremen, Germany, measured the level of social cohesion in 34 developed societies in order to demonstrate to the general public the origins and trends of social cohesion (Bertelsmann Stiftung, 2013). The Bertelsmann Stiftung model works at different levels of social systems. Therefore, this model has been successfully adopted and applied to the university community of National Pedagogical Dragomanov University (Nesterova, Dielini, Zamozhskyi, 2019). This model is described in Table 1.

To assess social cohesion, a survey was conducted at the NPDU, where 112 people, both employees and students, were interviewed. The interview consisted of 27 questions ( 3 questions for each aspect). The rating scale was 1 to 5 , where 1 represents low, 2 represents below average, 3 represents average, 4 represents

Table 1

The Model of Social Cohesion by Bertelsmann Stiftung (Bertelsmann Stiftung, 2013)

\begin{tabular}{|l|l|l|}
\hline \multicolumn{1}{|c|}{ Domain } & \multicolumn{1}{|c|}{ Aspect } & \multicolumn{1}{c|}{ Guideline } \\
\hline \multirow{4}{*}{ Social relations } & Social networks & People have strong, resilient social networks. \\
\cline { 2 - 3 } & Trust in people & People have a high level of trust in others. \\
\cline { 2 - 3 } & Acceptance of diversity & People accept individuals with different values and lifestyles as equal members of society. \\
\hline \multirow{4}{*}{ Connectedness } & Identification & People feel a strong connection to and identity with their country. \\
\cline { 2 - 3 } & Confidence in institutions & People have a high level of confidence in social and political institutions. \\
\cline { 2 - 3 } & Perception of justice & People believe that society's goods are fairly distributed and that they are being treated fairly. \\
\hline $\begin{array}{l}\text { Focusing on } \\
\text { the common } \\
\text { good }\end{array}$ & Solidarity and benevolence & People feel responsible for others and are willing to help them. \\
\cline { 2 - 3 } & Respect for social rules & People abide by the fundamental rules of society. \\
\cline { 2 - 3 } & Civic participation & People participate in public and political life, engage in public discussions. \\
\hline
\end{tabular}


above average, and 5 represents high. This study was conducted in 2019.

A year later, the level of confidence in this university was investigated and 116 people were interviewed. It was assumed that trust is a consequence of social cohesion and therefore it was proposed to measure confidence in the following categories: trust as a personal characteristic, credibility with a close circle of colleagues, confidence in the organization, trust in leaders, contractual trust, communication trust, competent trust, moral and ethical trust, and ecological trust. In this case, it is possible to consider confidence not only as a socio-philosophical phenomenon, but also as a parameter of the order of social synergy in the process of social self-organization the key factor of social cohesion, its cognitive mechanism and methodological foundation (Nesterova, Dielini, Yatsenko, 2020). This questionnaire consisted of 25 questions and was graded on a scale of 1 to 7 , where 1 was a negative answer and 7 was a strongly positive answer.

Another social phenomenon is social responsibility, and this phenomenon is closely related to social synergy and social cohesion and can be seen as an implementation of these. All of the above phenomena lead to sustainable development. It is possible to consider them as parameters of the order of social selforganization in open non-linear social systems.

A survey of European values in education was used to analyze social responsibility as a motivator for the sustainable development of universities, with participants answering which values are typical for them, which are incomprehensible or not shared, which are used by their colleagues or not shared by them, etc. Explored such value as "The responsibility of society for higher education and the responsibility of higher education itself", which can be seen as a social responsibility, as it means the responsibility of employees, the management of the university for their actions and the educational process. Social responsibility can also include such value as "Integrity," which means responsibility for one's academic achievements, honesty in the educational process, and consideration of other people's interests in one's university activities. There were 130 participants in this research. This questionnaire consisted of 12 questions that asked respondents and their colleagues to choose no more than 5 values that are shared or, conversely, not shared by them and other questions that help to conduct a quantitative analysis of the spread of European values of the educational system of Higher Education.

\section{Results}

In order to present results and substantiate the main idea of the research, to achieve the goal and to draw conclusions, the following figures were constructed. Figure 1 shows the results of a study of social cohesion by domain.

As can be seen from Figure 1, the highest result was in the domain of social relations, reflecting the

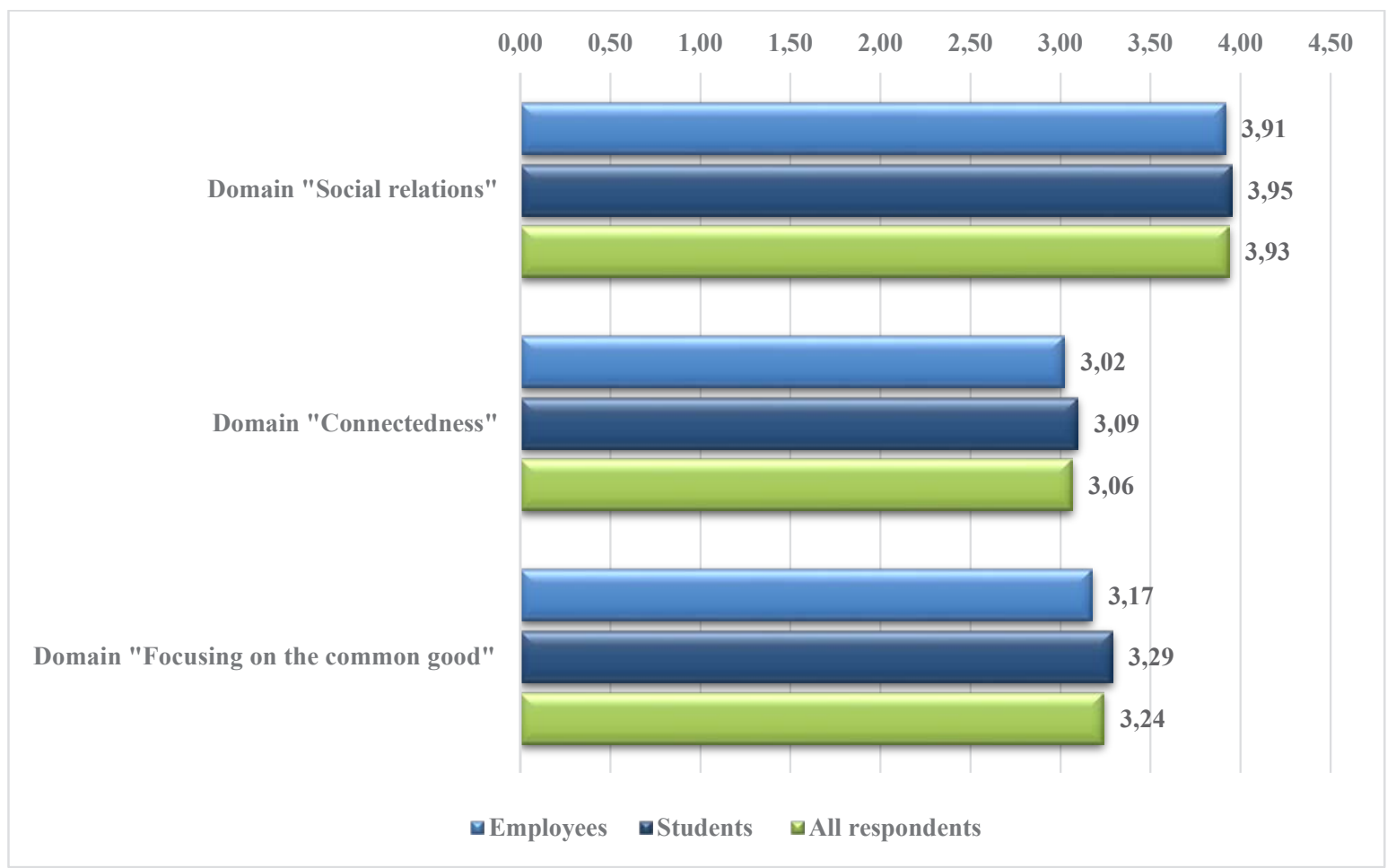

Figure 1. Evaluation of social cohesion by domain 
importance of social connections for respondents, the level of trust in other people, and the acceptance of diversity. The latter is also very important in the context of Ukraine's European integration path and the dissemination of the value of tolerance, which is absolute for the European community. This domain has the best result among the others, its score is almost equal to 4, which is higher than the average.

The domain "Connectedness" has slightly worse indicators, namely the lowest among all the groups and domains studied, although they are still above average.

The domain "Focusing on the common good" makes it possible to see that it has a better position than the previous one, and reflects people's orientation toward society, to help each other and to comply with social norms and rules. The results for the studied groups do not differ significantly.

It is noteworthy that the university staff has slightly lower rates compared to students.

For a more in-depth study of social cohesion in practice, it is possible to construct Figure 2, which shows the results of the study of social cohesion by aspects.

Analysis of social cohesion by aspects shows that social networks are equally important for both groups of the educational community studied, with slight differences downward for employees and upward for students. It can be concluded from this that it is slightly more important for students to have strong networks than for university staff. But in general, this parameter is quite important and can be regarded as one of the order parameters.

The trend of trust in people is almost the same, students have a higher level of trust, although the difference is not significant. The trust result is higher than the social networks result. Although the highest is the acceptance of diversity result. This aspect has a score above 4, and confidence in institution is almost 4.5. Also here there is a noticeable predominance of solidarity and benevolence in employees. The students have a much lower index.

Analysis of the domain "Connectedness" shows lower performance than the previous one. The

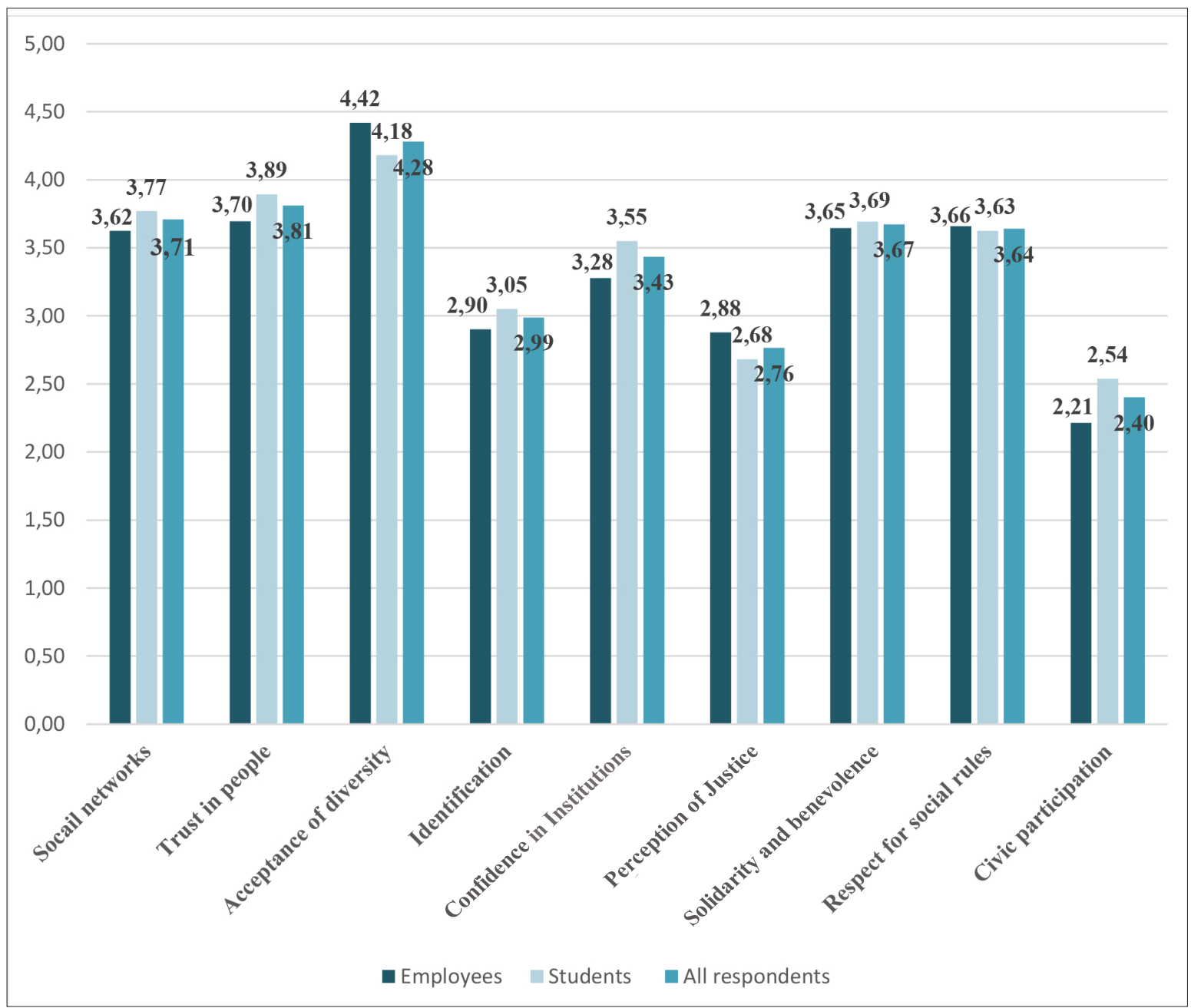

Figure 2. Evaluation of social cohesion by aspects 
"Identification" aspect is slightly greater than the perception of justice, but significantly lower than confidence in institutions. Moreover, students' confidence in institutions is higher than that of employees, and the perception of justice is the opposite. Students are less likely to perceive justice in relation to themselves.

An in-depth analysis of the latter area reflects results important to this article, taking into account the study of responsibility, since this area refers not only to cohesion, but also to responsibility. Thus, solidarity and benevolence derive from the value of responsibility to others. Adherence to norms and rules is a direct consequence of social responsibility as well as civic participation. The following results were obtained in this study: "solidarity and benevolence" and "respect for social rules" have almost identical scores among both employees and students. And civic participation differs in its outcome downward, and this difference is still noticeable. Which may indicate an insufficient level of readiness of our society to participate in public life.

In general, it can be concluded that the level of social cohesion in this university is at a sufficient (average) level, although there are small differences. This lays the foundation for a values-based sustainability strategy for the university.

To see the implications of the described level of social cohesion, it has been investigated trust as a value of a sustainable society (Figure 3 ). Since the object of this article is the field of education, it is reasonable to focus this sense on the values of higher education that are necessary for the sustainable development of universities.

As Figure 3 shows, the level of trust in the analyzed sample is above average, but not high enough. All of the trust categories in the respective fields had ratings ranging from 4.23 to 4.96 , although the measurement scale had a score of 7 . That is, despite the aboveaverage figure, they have not reached the level that can be characterized as a high level of trust.

The highest level of trust is Environmental Trust (ET) with a score of 4.96 (students' score of 5.06). This category of trust suggests that it is a necessary condition for stability in society. Transferring our study, it can be assumed that trust in the environment is a prerequisite for the sustainable development of the educational community. Also above the other indicators is trust in communication, as well as the result of trust in competence, and the lowest result is trust in leaders.

Thus, it cannot be said that trust among the analyzed educational community is high, despite the fact that the level of social cohesion in this sample is higher than trust.

For a more in-depth analysis of the values of the European community and the field of higher education, Figure 4 was formed, which shows the

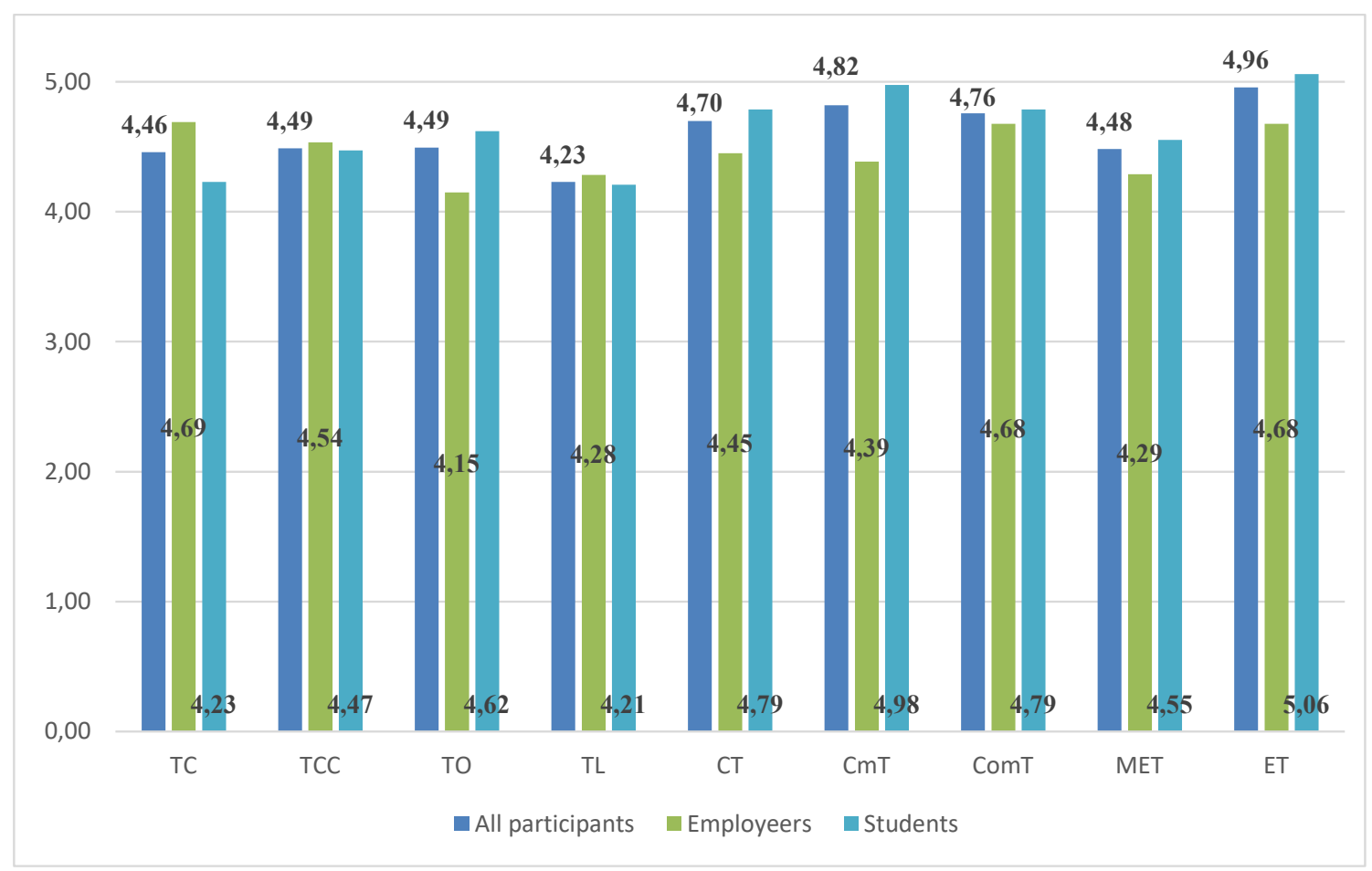

Figure 3. The level of trust in NPDU (where TC is trust as personal characteristic, TCC is trust to close circle of colleagues, TO is trust to a organization, TL is trust to leaders, CT is a contract trust, $\mathrm{CmT}$ - communication trust, ComT - competent trust, MET - moral and ethical trust, ET - environmental trust) 


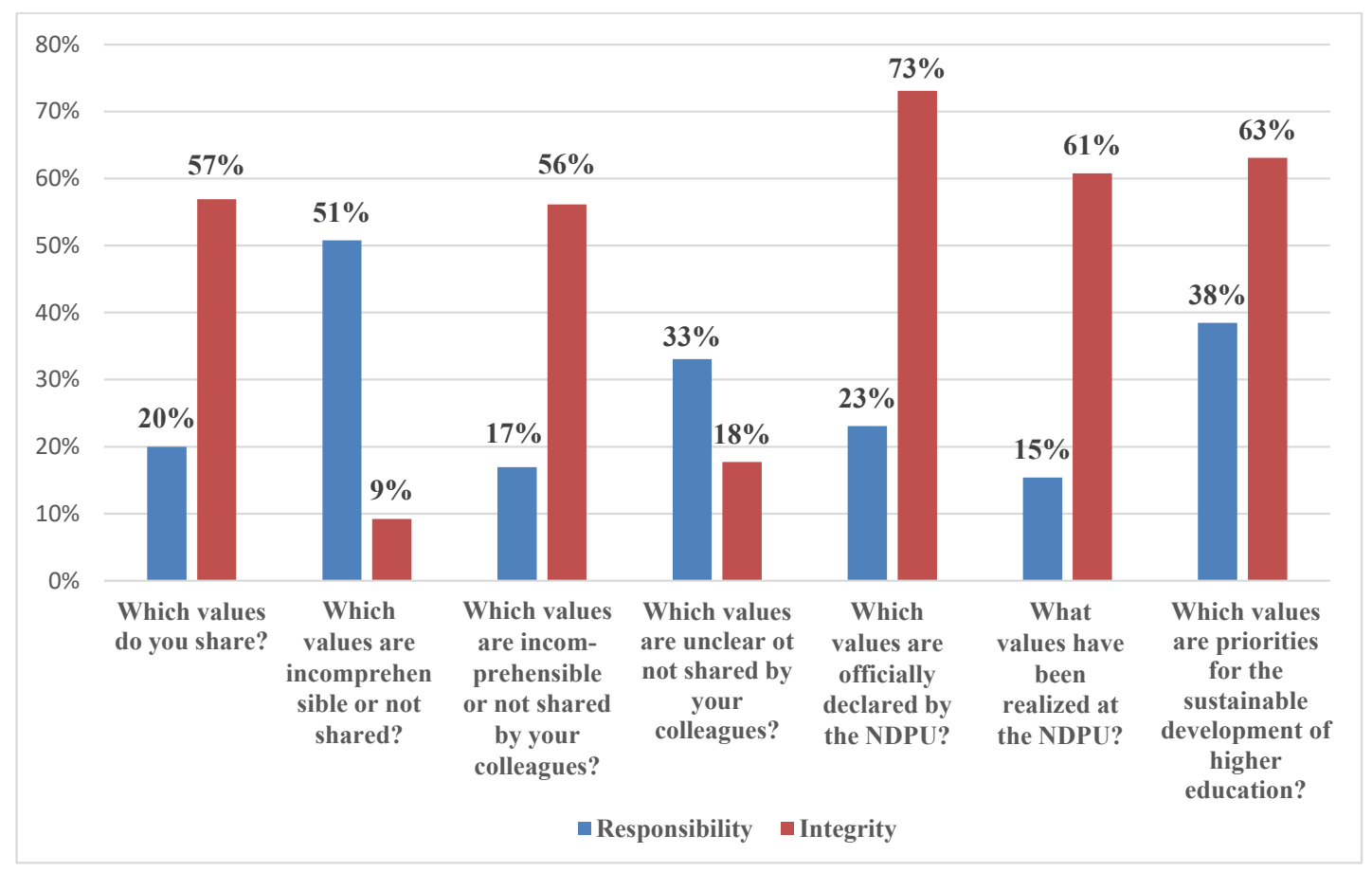

Figure 4. The survey of values of "Responsibility" and "Integrity" in the university

results of the survey of educators on values such as "Responsibility" and "Integrity".

Figure 4 shows that respondents currently share the value "Integrity" (57\% of respondents), and "Responsibility" is significantly fewer (20\%). The reason for this may be the answer to the following question about the incomprehension or unacceptability of this value. The results of these questions are drastically different, to be more precise, $51 \%$ of respondents do not comprehend and do not share "Responsibility" and only 9\% "Integrity". This suggests that this value is not widespread due to its incomprehensibility for our educators.

The next question about the distribution of values among colleagues reflected results identical to the first question, namely, 56\% shared the value of "Integrity" and only $17 \%$ shared the value of "Responsibility."

The situation is the same with Question 4, regarding the incomprehension of values by colleagues, with $33 \%$ of respondents believing that the value of "Responsibility" is incomprehensible or unacceptable to colleagues, and $18 \%$ believing that this applies to the value of "Integrity" as well.

Regarding which of these values the university recognizes or declares, respondents reported that 73 percent considered it "Integrity" and 23 percent "Responsibility".

Similarly, the majority (61\%) note that the value of "Integrity" is not only a declared value, but one that is practically realized in the NDPU, and only $15 \%$ gave the same answer regarding "Responsibility."
Concluding this survey, it can be noted that university representatives indicated that "Integrity" is a priority value for sustainability in higher education (63\%) and a smaller number, 38\%, identified "Responsibility" as a priority value.

Thus, it can be concluded that the value "Integrity" is quite developed and comprehensible in university community, which is a positive characteristic. On the contrary, the value "Responsibility" is less common, which may be due to its incomprehensibility for educators.

The studies are informative and reliable for extrapolation to present educational realities. Trust can be not only a result of social cohesion, but also a consequence of responsibility. Because responsible behavior forms the basis of trust in various institutions, including the university as an institution of higher education.

\section{Conclusions}

A synergetic view of the conditions for selforganization processes highlights two different roles for social responsibility and social cohesion as factors in the sustainable development of universities. Social responsibility is a value that functions as a controlling parameter of self-organization processes in the university community, directing it toward understanding social interests and serving them. Social cohesion is a parameter of order as an indicator of synergy (joint action) of educators and students, members of collectives becoming to solve important scientific 
and practical tasks. The university administration, in cooperation with the Ministry of Education and Science, should ensure the conditions for the formation of such communities and the maintenance of their activities. This means ensuring the sustainable development of universities.

This theoretical and practical research makes it possible to draw several conclusions. First, social responsibility and social cohesion are the driving forces of sustainable university development, since they imply joining efforts, uniting for a common goal, and taking responsibility for one's actions to society now and to future generations. Interviews conducted over the past 3 years have shown that the level of social cohesion is above average with slight variations by aspects, but, in general, this level is satisfactory. The analysis of trust, on the other hand, has less positive results, although the results of the survey are above average, but significantly lower than the possible maximum positive value.

An analysis of the value of responsibility, which in this study consists of two components, namely integrity and responsibility for higher education and higher education itself, showed that integrity is prevalent and recognized as important for the sustainable development of higher education. And the value of "public responsibility for higher education and higher education" leads to different results because it is not understood or acceptable to our colleagues in the educational community.

\section{Aknowledgements}

The authors gratefully appreciate all research participants. The research is the part of the project's implementation in the National Pedagogical Dragomanov University of Jean Monnet Project "European Values of Diversity and Inclusion for Sustainable Development" (EVDISD) 620545-EPP-12020-1-UA-EPPJMO-PROJECT (Erasmus + Program granted by European Commission). The European Commission's support for the production of this publication does not constitute an endorsement of the contents, which reflect the views only of the authors, and the Commission cannot be held responsible for any use which may be made of the information contained therein.

\section{References:}

Aleksandrova, O., Batchenko, L., Dielini, M., \& Lavryk, U. (2018). Specifics of managing competitiveness of present-day university on principles of social responsibility. Naukovyi Visnyk Natsionalnoho Hirnychoho Universytetu, (4), pp. 157-165. Available at: http://nvngu.in.ua/index.php/en/archive/on-the-issues/1622-2018/contents-4-2018/economy-andmanagement/4517-specifics-of-managing-competitiveness-of-present-day-university-on-principles-of-social-responsibility

Batchenko, L., Dielini, M., \& Honchar, L. (2020). A value-oriented polyparadigmal approach to the development of management education in the conditions of transformation change. Baltic Journal of Economic Studies, 6(5), 42-53. DOI: https://doi.org/ $10.30525 / 2256-0742 / 2020-6-5-42-53$

Batchenko, L., \& Dielini, M. (2017). International aspects of state regulation of socio-economic responsibility of entrepreneurship: experience for Ukraine. Baltic Journal of Economic Studies, 3(5), 13-18. DOI: https://doi.org/10.30525/22560742/2017-3-5-13-18

Benedict, R. (1970). Synergy: Patterns of the Good. Culture American Anthropologist, 72, 320-330.

Bertelsmann Stiftung: Social Cohesion Radar: Measuring common ground (2013) An international comparison of social cohesion. Gütersloh: Bertelsmann Stiftung, 76 p.

Corning, Peter A. (2011). The Fair Society: The Science of Human Nature and the Pursuit of Social Justice.

Dobronravova, I. (2021). Autopoesis in on line learning. Philosophy of Education, 1, 171-178. Available at: https://philosopheducation.com/index.php/philed/article/view/661

Dobronravova, I. S. (2001). Idea of Sustainable Development within the Framework of Sinergetic Conception //XXI Century: Dialogue of Civilizations and Sustainable Development. Abstracts of International Symposium. Ulan-Ude, p. 28. (in Russian)

Haken, H. (1995). An Introduction to Synergetics. Open Systems \& Information Dynamics, 3(1), 97-130. DOI: http://dx.doi.org/ $10.1007 / \mathrm{BF} 02228811$

Haken, H. (1996). Synergetics as a Bridge between the Natural and Social Sciences II Evolution, Order, and Complexity. London and N.Y., Routledge.

Jaffe, K. (2021). The thermodynamic roots of synergy and its impact on society. Available at: https://www.researchgate.net/ publication/318652480_The_thermodynamic_roots_of_synergy_and_its_impact_on_society

Jaffe, K., \& Zaballa, L. (2010). Co-Operative punishment cements social cohesion. Journal of Artificial Societies and Social Simulation, 13(3), 4. Available at: https://www.jasss.org/13/3/4.html

Jingyan, L. (2010). Study on application of synergetics in the sustainable development. International Conference on Future Information Technology and Management Engineering, 227-230. DOI: https://doi.org/10.1109/FITME.2010

Montoreano, C., \& Jaffe, K. (2013). Relative importance of social synergy, assortation and networks in the evolution of social cooperation, 1-12. Available at: https://arxiv.org/abs/1311.4407

Nesterova, M., Dielini, M., \& Zamozhskyi, A. (2019). Social cohesion in education: cognitive research in the university community. International Journal of Cognitive Research in Science, Engineering and Education (IJCRSEE), 7(2), 19-27. Available at: https://www.ijcrsee.com/index.php/ijcrsee/article/view/234 
Nesterova, M., Dielini, M., Shynkaruk, L., \& Yatsenko, O. (2020). Trust as a cognitive base of social cohesion in the university communities. International Journal of Cognitive Research in Science, Engineering and Education (IJCRSEE), 8(1). Available at: https://www.ijcrsee.com/index.php/ijcrsee/article/view/248

Peicheva, M. (2019). Social Responsibility of the Universities in Europe - Research of Diversity Of Practices (UK, Germany, France, Bulgaria). Economic Alternatives, 2, 235-250. Available at: https://ideas.repec.org/a/nwe/eajour/y2019i2p235-250.html

Voznyuk, A., \& Zdanevych, L. (2019). Application of System and Synergetic Paradigm of Management of Social-Economic, Educational Processes in Ukraine. Pedagogical Discourse, 26, 19-26. Available at: http://ojs.kgpa.km.ua/index.php/peddiscourse/ article/view/563/519 